Article

\title{
Decreased Erythrocyte CCS Content is a Biomarker of Copper Overload in Rats
}

\author{
Jesse Bertinato *, Lindsey Sherrard and Louise J. Plouffe
}

Nutrition Research Division, Health Products and Food Branch, Health Canada, Sir Frederick G. Banting Research Centre, 251 Sir Frederick Banting Driveway, Ottawa, Ontario, Canada;

E-Mails: lindsey.sherrard@hc-sc.gc.ca (L.S.); louise.j.plouffe@hc-sc.gc.ca (L.J.P.)

* Author to whom correspondence should be addressed; E-Mail: jesse.bertinato@hc-sc.gc.ca; Tel.: +1 613-957-0924; Fax: +1 613-941-6182.

Received: 26 May 2010; in revised form: 25 June 2010 / Accepted: 30 June 2010 /

Published: 2 July 2010

\begin{abstract}
Copper $(\mathrm{Cu})$ is an essential trace metal that is toxic in excess. It is therefore important to be able to accurately assess $\mathrm{Cu}$ deficiency or overload. $\mathrm{Cu}$ chaperone for $\mathrm{Cu} / \mathrm{Zn}$ superoxide dismutase (CCS) protein expression is elevated in tissues of $\mathrm{Cu}$-deficient animals. Increased CCS content in erythrocytes is particularly sensitive to decreased $\mathrm{Cu}$ status. Given the lack of a non-invasive, sensitive and specific biomarker for the assessment of $\mathrm{Cu}$ excess, we investigated whether CCS expression in erythrocytes reflects $\mathrm{Cu}$ overload. Rats were fed diets containing normal or high levels of $\mathrm{Cu}$ for 13 weeks. Diets contained $6.3 \pm 0.6(\mathrm{Cu}-\mathrm{N}), 985 \pm 14(\mathrm{Cu}-1000)$ or $1944 \pm 19(\mathrm{Cu}-2000) \mathrm{mg} \mathrm{Cu} / \mathrm{kg}$ diet. Rats showed a variable response to the high $\mathrm{Cu}$ diets. Some rats showed severe $\mathrm{Cu}$ toxicity, while other rats showed no visible signs of toxicity and grew normally. Also, some rats had high levels of $\mathrm{Cu}$ in liver, whereas others had liver $\mathrm{Cu}$ concentrations within the normal range. Erythrocyte CCS protein expression was 30\% lower in Cu-2000 rats compared to $\mathrm{Cu}-\mathrm{N}$ rats $(\mathrm{P}<0.05)$. Notably, only rats that accumulated high levels of $\mathrm{Cu}$ in liver had lower erythrocyte CCS (47\% reduction, P $<0.05)$ compared to rats fed normal levels of $\mathrm{Cu}$. Together, these data indicate that decreased erythrocyte CCS content is associated with $\mathrm{Cu}$ overload in rats and should be evaluated further as a potential biomarker for assessing $\mathrm{Cu}$ excess in humans.
\end{abstract}

Keywords: copper overload; CCS; biomarker; rat; erythrocytes 


\section{Introduction}

Copper $(\mathrm{Cu})$ is an essential trace metal that can cycle between reduced $\left(\mathrm{Cu}^{+}\right)$and oxidized $\left(\mathrm{Cu}^{2+}\right)$ forms. This property allows $\mathrm{Cu}$ to act as a catalytic co-factor for several metalloenzymes involved in a number of biochemical processes including cellular respiration, connective tissue formation, neurotransmitter production, pigment synthesis, antioxidant defense and iron homeostasis [1]. The ease in which $\mathrm{Cu}$ can cycle between oxidation states makes $\mathrm{Cu}$ a potentially toxic metal if allowed to accumulate to high levels. "Free" Cu not tightly bound to proteins or other molecules can participate in Fenton-type reactions generating the toxic hydroxyl radical that can damage cellular components. Because $\mathrm{Cu}$ is both an essential and potentially toxic metal, cells have evolved transporters that regulate the uptake or elimination of $\mathrm{Cu}$ [2,3]. Also, $\mathrm{Cu}$ chaperones bind $\mathrm{Cu}$ in cells and deliver the metal to specific enzymes or subcellular compartments preventing the accumulation of "free" $\mathrm{Cu}$ [4].

Disruption of Cu-trafficking systems can lead to Cu deficiency or toxicity. Examples are the genetic disorders Menkes' and Wilson's disease. Menkes' disease is caused by impaired activity of the $\mathrm{Cu}$ efflux transporter ATP7A which leads to a systemic $\mathrm{Cu}$ deficiency due to defective intestinal $\mathrm{Cu}$ uptake [5]. Wilson's disease is the result of impaired activity of the Cu efflux transporter ATP7B [6,7]. Wilson's disease results in Cu overload in liver and other tissues due to impaired biliary Cu excretion.

A nutritional $\mathrm{Cu}$ deficiency results in decreased activity of Cu-dependent enzymes and consequently decreased efficiency of a number of biochemical processes. A decrease in $\mathrm{Cu}$ status produces a number of biological changes and many of these changes have been proposed as biomarkers of $\mathrm{Cu}$ deficiency. These have been recently reviewed [8]. Importantly, fewer changes have been described in response to $\mathrm{Cu}$ overload. At present, an ideal biomarker for assessing Cu overload is lacking. Elevated $\mathrm{Cu}$ content in liver is currently regarded as the most reliable measure of Cu overload. However, this test requires a liver biopsy which is an invasive procedure. Thus, liver Cu measurement is unsuitable for routine screening and is only justified when $\mathrm{Cu}$ overload is suspected such as in patients with assumed Wilson's disease. Furthermore, the uneven $\mathrm{Cu}$ distribution in liver may result in misdiagnosis of $\mathrm{Cu}$ overload with a single biopsy specimen [9-11].

Liver damage is a symptom of $\mathrm{Cu}$ toxicity. Alanine aminotransferase (ALT) and aspartate aminotransferase (AST) are elevated in serum when liver damage occurs and therefore can be used to assess $\mathrm{Cu}$ toxicity. However, increased ALT and AST levels are not specific for Cu toxicity and are only increased once tissue damage has occurred. Elevated 24 hour urine $\mathrm{Cu}$ content is also used to assess Cu overload, particularly in patients with Wilson's disease [12]. Drawbacks of this test are that multiple urine samples must be collected and possible contamination of samples at collection. Urinary $\mathrm{Cu}$ may also be unsuitable for detection of more subtle increases in $\mathrm{Cu}$ load. Further, high urinary $\mathrm{Cu}$ may be unrelated to $\mathrm{Cu}$ excess [13]. Plasma or serum non-ceruloplasmin (Cp)-bound $\mathrm{Cu}$ is a promising biomarker for assessing $\mathrm{Cu}$ overload, although a convenient method for direct and accurate measurement of this $\mathrm{Cu}$ fraction is needed. Direct measurement of "free" $\mathrm{Cu}$ in serum or plasma ultrafiltrate (molecular weight cut-off of $30 \mathrm{kDa}$ ) by inductively coupled mass spectrometry revealed elevated levels in untreated patients with Wilson's disease [14]. These data warrant further research on the specificity and sensitivity of this marker.

Given the lack of a sensitive and specific biomarker that can be measured with a simple, non-invasive test, research characterizing potentially better biomarkers of $\mathrm{Cu}$ overload is needed. $\mathrm{Cu}$ 
chaperone for $\mathrm{Cu} / \mathrm{Zn}$ superoxide dismutase (CCS) is a homodimeric protein of $~ 33 \mathrm{kDa}$ subunits and functions to deliver $\mathrm{Cu}$ to the antioxidant enzyme $\mathrm{Cu} / \mathrm{Zn}$ superoxide dismutase (SOD1) [15]. We have previously reported that CCS protein is increased in liver and erythrocytes of Cu-deficient rats [16]. Others have shown similar increases in CCS protein in tissues using different animal models of $\mathrm{Cu}$ deficiency [17-19]. Up-regulation of CCS under conditions of Cu deficiency was determined to result from decreased degradation of CCS protein by the 26S proteasome [20]. Further work showed that $\mathrm{Cu}$ binding to the CXC (C, cysteine; X, any amino acid) Cu-binding motif in the C-terminus of CCS decreases CCS stability and promotes proteasomal degradation [21].

CCS expression in erythrocytes is particularly sensitive to $\mathrm{Cu}$ deficiency. We have shown that erythrocyte CCS protein is a sensitive biomarker of mild Cu deficiency induced by moderately high intakes of zinc in rats [22]. Increased erythrocyte CCS expression was determined to be more sensitive to mild reductions in $\mathrm{Cu}$ status compared to plasma $\mathrm{Cu}$ concentration or $\mathrm{Cp}$ activity [22], the two most widely used markers for assessing $\mathrm{Cu}$ deficiency. A recent study has indicated that erythrocyte and liver CCS protein is increased in Cu-deficient calves and CCS may serve as a good biomarker of $\mathrm{Cu}$ deficiency in cattle [19]. Also, liver and erythrocyte CCS did not change in response to a vaccineinduced inflammatory response in beef heifers indicating that CCS expression was not affected by an inflammatory response unlike plasma $\mathrm{Cu}$ and $\mathrm{Cp}$ which are elevated under such conditions [19].

CCS is currently regarded as a promising biomarker for assessing $\mathrm{Cu}$ deficiency [8]. However, to our knowledge there are no reports describing regulation of CCS protein expression in response to $\mathrm{Cu}$ overload in animals. A human study showed that CCS and SOD1 mRNA were reduced in peripheral mononuclear cells of healthy adults with high serum Cp concentrations following supplementation with $10 \mathrm{mg} \mathrm{Cu}$ per day for 60 days [23]. Notably, however, similar reductions in CCS and SOD1 mRNA were not detected in subjects with low Cp concentrations. These data warrant further characterization of these markers. In this study, we measured CCS protein expression in erythrocytes of rats fed high $\mathrm{Cu}$ diets as a first step in determining the potential of erythrocyte CCS to serve as a biomarker for assessing Cu overload.

\section{Results and Discussion}

Rats were used to investigate whether erythrocyte CCS protein expression is altered in response to $\mathrm{Cu}$ overload. Although rats are tolerant to dietary $\mathrm{Cu}$ levels much greater than amounts needed to maintain adequate $\mathrm{Cu}$ status, dietary levels needed to induce increases in body $\mathrm{Cu}$ levels and toxicity have been established [24-27]. Rats were fed a diet containing normal amounts of $\mathrm{Cu}$ (Cu-N diet) or one of two diets containing high levels of $\mathrm{Cu}$ (diets $\mathrm{Cu}-1000$ and $\mathrm{Cu}-2000$ ) for 13 weeks. Diets contained $6.3 \pm 0.6,985 \pm 14$ or $1944 \pm 19 \mathrm{mg} \mathrm{Cu} / \mathrm{kg}$ diet by analysis (Table 1). For the entire duration of the study, all rats fed the $\mathrm{Cu}-1000$ diet grew normally and did not show any visible signs of $\mathrm{Cu}$ toxicity. In contrast, 1 of the 12 rats fed the $\mathrm{Cu}-2000$ diet was found dead after 6 weeks on the diet. An additional 4 rats in this diet group were euthanized due to weight loss, diarrhoea and dehydration after 7 (3 rats) and 10 (1 rat) weeks on the diet. Internal examination indicated damage to several tissues. Rats had a distended stomach and cecum, enlarged kidneys with a pale brown discolouration and rough surface and a moderately enlarged spleen. The liver had a pale brown discolouration. 
Table 1. Cu content in test diets and body weight of rats ${ }^{1}$.

\begin{tabular}{cccc}
\hline Diet Group & $\begin{array}{c}\text { Test Diets } \\
(\mathbf{m g ~ C u} / \mathbf{k g ~ d i e t})^{2}\end{array}$ & $\begin{array}{c}\text { Initial Body Weight } \\
\mathbf{( g )}^{\mathbf{3}}\end{array}$ & $\begin{array}{c}\text { Final Body weight } \\
\mathbf{( g )}^{\mathbf{3}}\end{array}$ \\
\hline $\mathrm{Cu}-\mathrm{N}$ & $6.3 \pm 0.6^{\mathrm{a}}$ & $112 \pm 2.9^{\mathrm{a}}$ & $554 \pm 6.5^{\mathrm{a}}$ \\
$\mathrm{Cu}-1000$ & $985 \pm 14^{\mathrm{b}}$ & $109 \pm 2.7^{\mathrm{a}}$ & $571 \pm 16^{\mathrm{a}}$ \\
$\mathrm{Cu}-2000$ & $1944 \pm 19^{\mathrm{c}}$ & $114 \pm 1.0^{\mathrm{a}}$ & $603 \pm 15^{\mathrm{a}, 4}$ \\
\hline
\end{tabular}

${ }^{1}$ Values are means \pm SEM. Values in a column without a common letter differ, $\mathrm{P}<0.05 .{ }^{2} \mathrm{n}=3 .{ }^{3} \mathrm{n}=12 .{ }^{4} \mathrm{n}=7$.

Elevated levels of serum ALT and AST are indicative of damage to the liver or other tissues. Increased serum blood urea nitrogen (BUN) and creatinine levels are commonly used to diagnose impaired kidney function. Serum ALT levels were above the reference interval in 2 of the 4 euthanized rats, while serum AST, BUN and creatinine levels were elevated in all 4 of these rats (data not shown). Results of these biochemical tests are consistent with the morphological alterations indicative of $\mathrm{Cu}$-induced damage to the liver, kidneys and other tissues. Haematological measurements indicated that these rats were also anaemic. They had low erythrocyte counts and Hb values (data not shown).

Rats have the ability to adapt to high dietary levels of $\mathrm{Cu}$. Rats fed high levels of $\mathrm{Cu}$ (3,000-6,000 mg Cu/kg diet) showed an initial rapid rise in liver $\mathrm{Cu}$ concentration followed by a decline in liver $\mathrm{Cu}$ over several weeks [27]. Despite the severe $\mathrm{Cu}$-induced toxicity observed in 5 rats fed the $\mathrm{Cu}$ 2000 diet, the remaining 7 rats in this diet group grew normally and did not show any adverse effects from the high $\mathrm{Cu}$ diet. Body weights of rats fed the $\mathrm{Cu}-\mathrm{N}, \mathrm{Cu}-1000$ or $\mathrm{Cu}-2000$ diets were similar after 13 weeks on the diets (Table 1). The resistance of some rats to severe $\mathrm{Cu}$ toxicity indicates that these rats adapted to the high $\mathrm{Cu}$ diet. The variable response of the rats may be explained, in part, by genetic heterogeneity of the Wistar rat strain which allowed some rats to better adapt to the high Cu diet.

Internal examination of rats fed the $\mathrm{Cu}-1000$ or $\mathrm{Cu}-2000$ diets that completed the study revealed no significant morphological changes to tissues. Most haematological parameters were similar for $\mathrm{Cu}-\mathrm{N}$, $\mathrm{Cu}-1000$ or $\mathrm{Cu}-2000$ rats (Table 2). However, MCHC values were lower and RDW values were higher for $\mathrm{Cu}-2000$ rats compared to $\mathrm{Cu}-\mathrm{N}$ rats indicating that the $\mathrm{Cu}-2000$ diet induced a decrease in haemoglobin concentration in a packed volume of erythrocytes and larger variation in the size of erythrocytes.

Table 2. Erythrocytes (ERCS), haemoglobin (Hb), haematocrit (HCT), mean corpuscular volume (MCV), mean corpuscular haemoglobin $(\mathrm{MCH})$, mean corpuscular haemoglobin concentration (MCHC), red cell distribution width (RDW), platelet count (PLT), mean platelet volume (MPV) and white blood cells (WBC) of rats fed diets normal or high in $\mathrm{Cu}$ for 13 weeks ${ }^{1}$.

\begin{tabular}{|c|c|c|c|c|c|c|c|c|c|c|}
\hline $\begin{array}{c}\text { Diet Group } \\
\text { (n) }\end{array}$ & $\begin{array}{c}\text { ERCS } \\
\left(10^{12} / \mathrm{L}\right)\end{array}$ & $\begin{array}{c}\mathrm{Hb} \\
(\mathrm{g} / \mathrm{L})\end{array}$ & HCT & $\begin{array}{l}\text { MCV } \\
\text { (fL) }\end{array}$ & $\begin{array}{c}\text { MCH } \\
\text { (pg) }\end{array}$ & $\begin{array}{c}\text { MCHC } \\
(\mathrm{g} / \mathrm{L})\end{array}$ & $\begin{array}{c}\text { RDW } \\
(\%)\end{array}$ & $\begin{array}{c}\text { PLT } \\
\left(10^{9} / \mathrm{L}\right.\end{array}$ & $\begin{array}{l}\text { MPV } \\
\text { (fL) }\end{array}$ & $\begin{array}{c}\text { WBC } \\
\left(10^{9} / \mathrm{L}\right)\end{array}$ \\
\hline Cu-N (12) & $7.8 \pm 0.1^{a}$ & $138 \pm 2^{\mathrm{a}}$ & $0.40 \pm 0.01^{\mathrm{a}}$ & $51.5 \pm 0.2^{\mathrm{a}}$ & $17.8 \pm 0.1^{\mathrm{a}}$ & $344 \pm 1^{\mathrm{a}}$ & $12.2 \pm 0.2^{\mathrm{a}}$ & $714 \pm 29^{\mathrm{a}}$ & $6.6 \pm 0.08^{\mathrm{a}}$ & $3.9 \pm 0.3^{\mathrm{a}}$ \\
\hline Cu-1000 (12) & $8.1 \pm 0.1^{\mathrm{a}}$ & $138 \pm 1^{\mathrm{a}}$ & $0.40 \pm 0.00^{\mathrm{a}}$ & $50.3 \pm 0.4^{\mathrm{a}}$ & $17.1 \pm 0.2^{\mathrm{a}}$ & $341 \pm 1^{\mathrm{a}, \mathrm{b}}$ & $13.1 \pm 0.2^{\mathrm{a}, \mathrm{b}}$ & $723 \pm 36^{\mathrm{a}}$ & $6.6 \pm 0.08^{\mathrm{a}}$ & $4.5 \pm 0.4^{\mathrm{a}}$ \\
\hline Cu-2000 (7) & $8.0 \pm 0.1^{\mathrm{a}}$ & $134 \pm 4^{\mathrm{a}}$ & $0.40 \pm 0.01^{\mathrm{a}}$ & $49.3 \pm 1.2^{\mathrm{a}}$ & $16.7 \pm 0.5^{\mathrm{a}}$ & $338 \pm 2^{\mathrm{b}}$ & $13.7 \pm 0.5^{\mathrm{b}}$ & $777 \pm 29^{\mathrm{a}}$ & $6.6 \pm 0.16^{\mathrm{a}}$ & $4.9 \pm 0.3^{\mathrm{a}}$ \\
\hline
\end{tabular}


$\mathrm{Cp}$ is a Cu-containing enzyme released into the circulation from the liver. Depressed Cp activity is a widely used marker for assessing $\mathrm{Cu}$ deficiency. Plasma $\mathrm{Cp}$ activity did not differ between rats fed normal or high $\mathrm{Cu}$ (Table 3). Serum ALT also did not differ in rats fed the different diets (Table 3). However, 1 rat fed the $\mathrm{Cu}-2000$ diet had an ALT level above the reference interval. Serum AST was higher in $\mathrm{Cu}-2000$ rats compared to $\mathrm{Cu}-\mathrm{N}$ rats (Table 3) and 6 of 12 rats fed the $\mathrm{Cu}-1000$ diet and 4 of 7 rats fed the Cu-2000 diet had AST levels above the reference interval. Since an elevation in AST is not specific for liver damage, we cannot say whether the increases in AST reflect liver damage or damage to other tissues. Notably, ALT which is considered a more specific enzyme for liver damage was within the reference interval for 18 of 19 rats fed the high $\mathrm{Cu}$ diets that completed the study. Serum BUN and creatinine levels were similar in $\mathrm{Cu}-\mathrm{N}, \mathrm{Cu}-1000$ or $\mathrm{Cu}-2000$ rats (Table 3) and levels were not elevated for any of the rats suggesting the absence of significantly impaired renal function in rats fed high $\mathrm{Cu}$ that completed the study.

Table 3. Plasma Cp activity and serum ALT, AST, BUN and creatinine of rats fed diets normal or high in $\mathrm{Cu}$ for 13 weeks ${ }^{1,2,3}$.

\begin{tabular}{cccccc}
\hline $\begin{array}{c}\text { Diet Group } \\
(\mathbf{n})\end{array}$ & $\begin{array}{c}\text { Cp } \\
(\mathbf{U} / \mathbf{L})\end{array}$ & $\begin{array}{c}\text { ALT } \\
(\mathbf{U} / \mathbf{L})\end{array}$ & $\begin{array}{c}\text { AST } \\
(\mathbf{U} / \mathbf{L})\end{array}$ & $\begin{array}{c}\text { BUN } \\
(\mathbf{m g} / \mathbf{d L})\end{array}$ & $\begin{array}{c}\text { Creatinine } \\
(\mu \mathbf{m o l} / \mathbf{L})\end{array}$ \\
\hline $\mathrm{Cu}-\mathrm{N}$ & $168 \pm 7.0^{\mathrm{a}}$ & $36 \pm 5.1^{\mathrm{a}}$ & $89 \pm 5.1^{\mathrm{a}}$ & $17 \pm 0.8^{\mathrm{a}}$ & $39 \pm 1.7^{\mathrm{a}}$ \\
$(12)$ & $(140-208)$ & $(23-87)$ & $(62-113)$ & $(13-23)$ & $(30-50)$ \\
$\mathrm{Cu}-1000$ & $163 \pm 7.7^{\mathrm{a}}$ & $50 \pm 5.7^{\mathrm{a}}$ & $156 \pm 19^{\mathrm{a}, \mathrm{b}}$ & $17 \pm 1.3^{\mathrm{a}}$ & $37 \pm 2.3^{\mathrm{a}}$ \\
$(12)$ & $(127-230)$ & $(29-102)$ & $(67-302)$ & $(12-26)$ & $(25-52)$ \\
$\mathrm{Cu}-2000$ & $180 \pm 10^{\mathrm{a}}$ & $80 \pm 25^{\mathrm{a}}$ & $253 \pm 68^{\mathrm{b}}$ & $15 \pm 1.1^{\mathrm{a}}$ & $39 \pm 2.4^{\mathrm{a}}$ \\
$(7)$ & $(141-222)$ & $(25-202)$ & $(87-532)$ & $(12-20)$ & $(29-48)$ \\
\hline
\end{tabular}

${ }^{1}$ Values are means \pm SEM. Values in a column without a common letter differ, $\mathrm{P}<0.05$.

${ }^{2}$ The data range is indicated in parenthesis below each value.

${ }^{3}$ Reference intervals: ALT (0-186 U/L); AST (0-156 U/L); BUN (12.62-26.09 mg/dL); creatinine (31.6-65.6 $\mu \mathrm{mol} / \mathrm{L})$.

Liver $\mathrm{Cu}$ concentration for most rats fed high $\mathrm{Cu}$ were not markedly elevated (16-69 $\mu \mathrm{g} / \mathrm{g}$ dry weight) (Figure 1A). In 4 rats, 1 rat fed the $\mathrm{Cu}-1000$ diet and 3 rats fed the $\mathrm{Cu}-2000$ diet, liver $\mathrm{Cu}$ concentration was markedly elevated (564-1058 $\mu \mathrm{g} / \mathrm{g}$ dry weight) (Figure 1A). These levels are comparable to liver Cu concentrations seen in Wilson's patients [11,28]. Despite high liver Cu, these rats did not show any visual signs of $\mathrm{Cu}$ toxicity. Only 1 rat (fed the $\mathrm{Cu}-2000$ diet) had considerably elevated $\mathrm{Cu}$ in kidney (Figure $1 \mathrm{~B}$ ). This rat also had high liver $\mathrm{Cu}$. Plasma $\mathrm{Cu}$ levels were not significantly different between $\mathrm{Cu}-\mathrm{N}, \mathrm{Cu}-1000$ or $\mathrm{Cu}-2000$ rats $(\mathrm{P}>0.05)$ (Figure 1C). Notably, however, the highest plasma $\mathrm{Cu}$ concentrations were detected in the 4 rats that also had the highest liver $\mathrm{Cu}$ concentrations.

The variable response of rats to high dietary $\mathrm{Cu}$ was striking. Some rats showed normal Cu levels in tissues, while others accumulated high amounts of $\mathrm{Cu}$. Furthermore, some rats showed severe $\mathrm{Cu}$ toxicity warranting euthanasia, whereas others accumulated high levels of $\mathrm{Cu}$ in tissues with little or no pathology. Although humans and rats differ in their sensitivity to $\mathrm{Cu}$, these data merit research examining the interindividual variability of humans to $\mathrm{Cu}$ accumulation and toxicity in response to 
high $\mathrm{Cu}$ intakes. These data also stress the importance of assessing $\mathrm{Cu}$ status with a biomarker that reflects tissue $\mathrm{Cu}$ load rather than by $\mathrm{Cu}$ intake estimates.

Figure 1. Cu concentrations in liver (A), kidney (B) and plasma (C) of rats fed diets with normal or high amounts of $\mathrm{Cu}$. Each solid circle corresponds to 1 rat, $\mathrm{n}=12,12$ and 7 for Cu-N, Cu-1000 and Cu-2000, respectively.

A

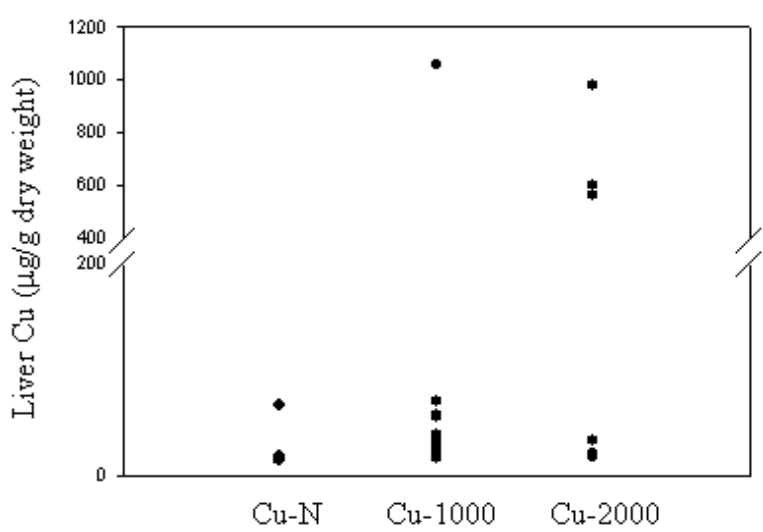

$\mathrm{B}$

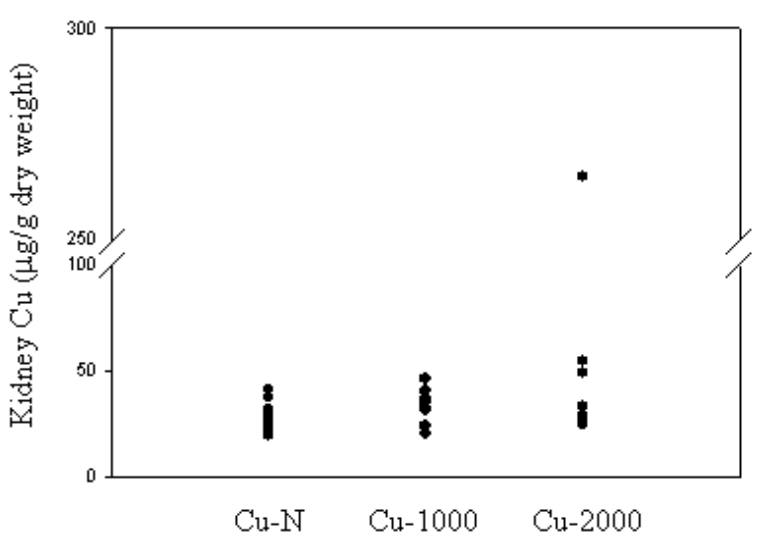

$\mathrm{C}$

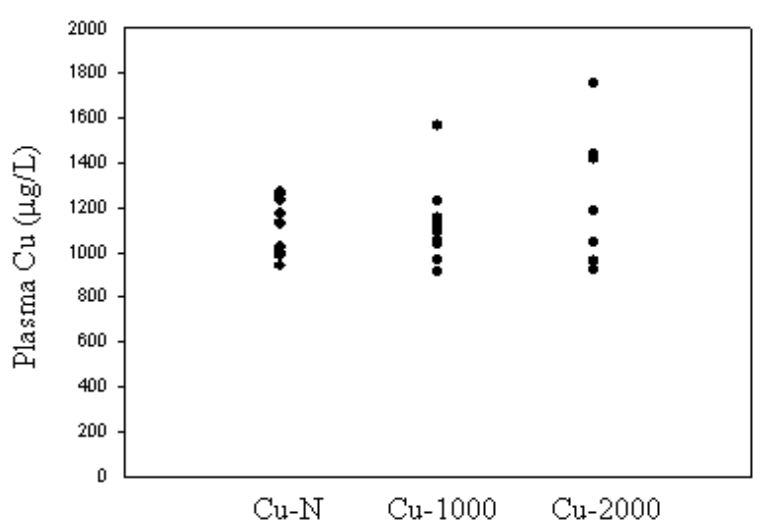

CCS protein content in erythrocytes was measured by Western blot using a CCS-specific antibody. CCS expression was expressed relative to GAPDH content since erythrocyte GAPDH protein has been shown to be unaffected by changes in $\mathrm{Cu}$ status [17]. Erythrocyte CCS was reduced by $30 \%$ in $\mathrm{Cu}-2000$ rats compared to $\mathrm{Cu}-\mathrm{N}$ rats (Figure 2). CCS was not lower in $\mathrm{Cu}-1000$ rats compared to Cu-N rats (Figure 2). Given that only some rats fed the high $\mathrm{Cu}$ diets accumulated high levels of $\mathrm{Cu}$ in liver, 
we chose to compare CCS expression in these rats with rats fed normal $\mathrm{Cu}$ or rats fed high $\mathrm{Cu}$ without marked accumulation of $\mathrm{Cu}$ in liver. Rats that accumulated high $\mathrm{Cu}$ in liver had lower CCS (47\% decrease) compared to rats fed a normal $\mathrm{Cu}$ diet (Figure 3). Furthermore, rats with high liver $\mathrm{Cu}$ also had lower CCS compared to rats fed high $\mathrm{Cu}$ but did not show marked accumulation of $\mathrm{Cu}$ in liver (Figure 3A). Taken together, these results indicate that reduced CCS protein in erythrocytes is associated with increased body $\mathrm{Cu}$ load and not high dietary $\mathrm{Cu}$ intake per se.

In this study, we investigated the change in erythrocyte CCS in response to Cu overload only in male rats. It will therefore be important to test whether CCS responds in a similar manner in females. It should be noted, however, that CCS content has been shown to be elevated in tissues and erythrocytes of both male and female Cu-deficient rats and mice [17,18].

Figure 2. Relative CCS content in erythrocytes of rats fed the $\mathrm{Cu}-\mathrm{N}, \mathrm{Cu}-1000$ or $\mathrm{Cu}-2000$ diets. The mean of $\mathrm{Cu}-\mathrm{N}$ rats was arbitrarily set to 1 . CCS expression is expressed relative to GAPDH expression. Values are means \pm SEM. Bars without a common letter differ, $\mathrm{P}<0.05$.

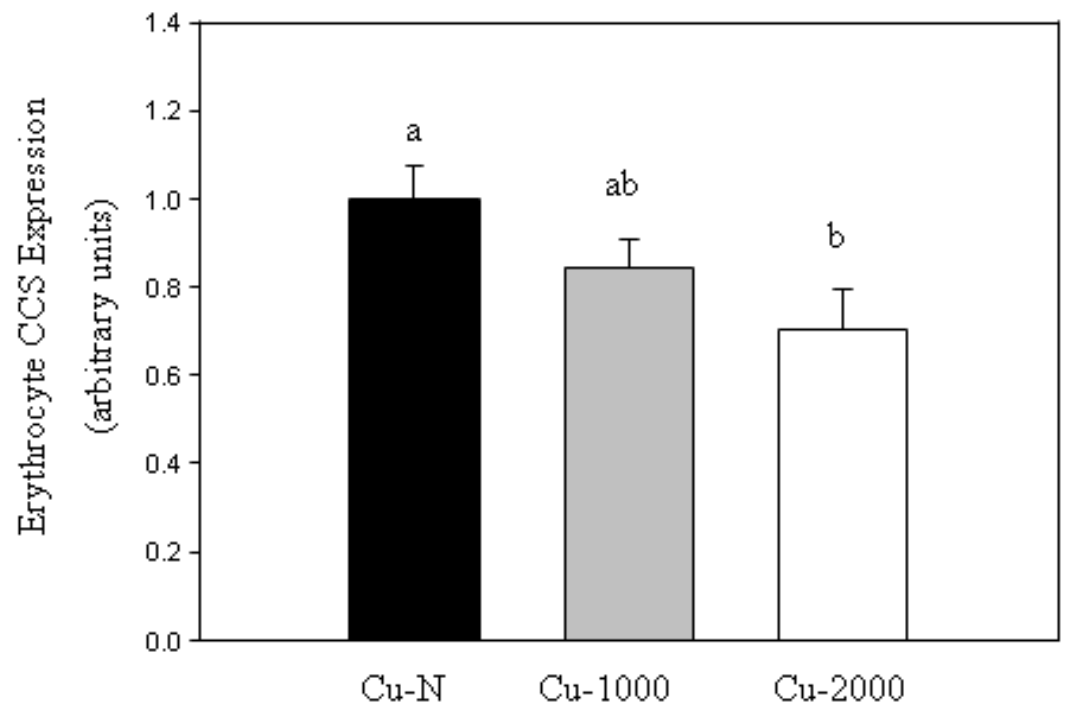

In cells, $\mathrm{Cu}$ binding to CCS decreases CCS stability and promotes its degradation by the 26S proteasome [20,21]. Decreased CCS protein in erythrocytes of Cu-loaded rats is consistent with the mechanism of CCS regulation by $\mathrm{Cu}$. Given that mature erythrocytes are anucleated, regulation of CCS content in response to $\mathrm{Cu}$ overload may occur during erythropoiesis in maturing erythrocytes that have a nucleus and can efficiently support protein turnover. Under conditions of $\mathrm{Cu}$ overload, maturing erythrocytes may be exposed to higher levels of $\mathrm{Cu}$. Higher cellular $\mathrm{Cu}$ concentrations would be expected to increase CCS degradation and consequently result in lower levels of CCS in mature erythrocytes. Notably, if CCS regulation by Cu occurs in maturing erythrocytes, a measurable decrease in CCS content in mature circulating erythrocytes would not be detected immediately following acute $\mathrm{Cu}$ overload. A detectable decrease in CCS would depend on the synthesis of a significant amount of new erythrocytes exposed to high $\mathrm{Cu}$ during maturation. Therefore, lower erythrocyte CCS content would be indicative of chronic Cu overload. 
Figure 3. Relative CCS expression in erythrocytes of rats fed diets with normal amounts of $\mathrm{Cu}(\mathrm{Cu}-\mathrm{N})$ or high levels of $\mathrm{Cu}$ displaying high (High Liver $\mathrm{Cu}$ ) or normal (Normal Liver $\mathrm{Cu}$ ) liver $\mathrm{Cu}$ concentrations. CCS expression in erythrocytes was quantified and expressed relative to GAPDH expression (A). The mean for $\mathrm{Cu}-\mathrm{N}$ rats was arbitrarily set to 1 . Values are means \pm SEM, $\mathrm{n}=7,4$ and 10 for $\mathrm{Cu}-\mathrm{N}$, High Liver $\mathrm{Cu}$ and Normal Liver $\mathrm{Cu}$, respectively. Bars without a common letter differ, $\mathrm{P}<0.05$. Representative Western blot showing erythrocyte CCS expression in rats fed normal $\mathrm{Cu}(\mathrm{Cu}-\mathrm{N})$ or rats fed high $\mathrm{Cu}$ and having high liver $\mathrm{Cu}$ concentrations (High Liver $\mathrm{Cu}$ ) (B). CCS expression was detected with a CCS-specific antibody (top panel). The membrane was stripped and probed with an antibody against GAPDH (bottom panel).

A

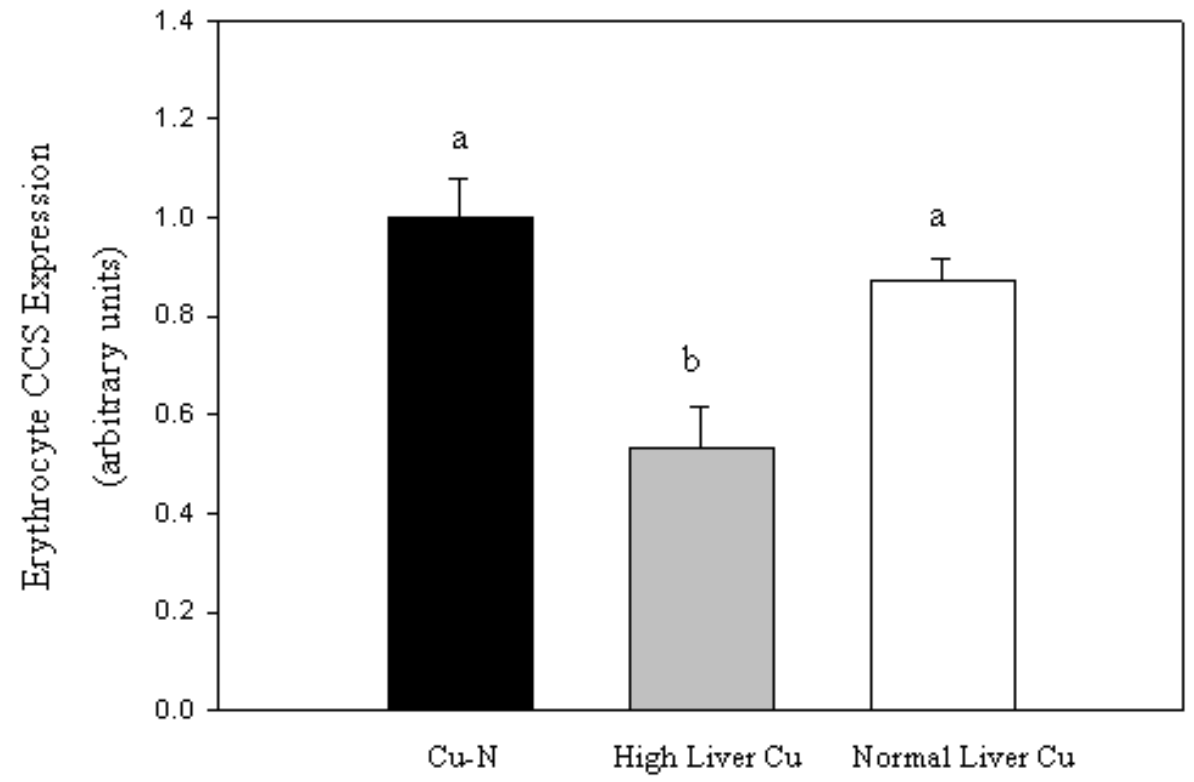

B

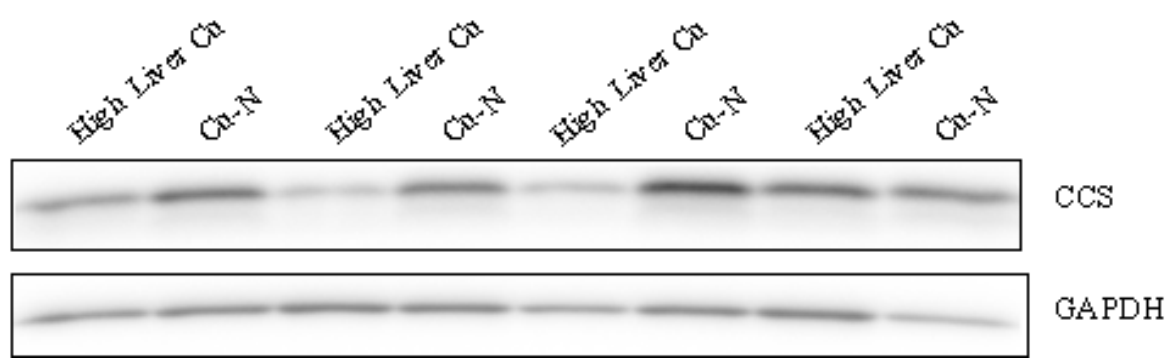

\section{Experimental Section}

\subsection{Animals and Test Diets}

Male 31-day-old Wistar rats (Charles River Canada, St. Constant, Canada) had free access to 1 of 3 test diets ( $n=12$ /diet group) and demineralised drinking water. Diets were modified AIN-93G diets similar to diets described previously [16]. Cu was added to the diets as cupric carbonate. Diets differed 
only in $\mathrm{Cu}$ content. $\mathrm{Cu}$ concentrations in samples of each diet were determined by flame atomic absorption spectrophotometry (AAS) (Perkin-Elmer 5100 PC; Perkin Elmer Cetus Instruments, Norwalk, CT). After 13 weeks of feeding the diets, rats were killed by exsanguination while anesthetised with 3\% isoflurane. Blood was collected from the abdominal aorta for biochemical tests and determination of haematological parameters. Blood was also collected in $\mathrm{K}_{2}$ EDTA Trace Element tubes (Fisher Scientific, Ottawa, Canada) for isolation of erythrocytes and plasma. The liver and right kidney were extracted and snap frozen in liquid nitrogen and then stored at $-80{ }^{\circ} \mathrm{C}$ until analysis. The Health Products and Food Branch Animal Care Committee of Health Canada approved the experimental protocol. Rats were treated in accordance with the guidelines of the Canadian Council on Animal Care.

\subsection{Blood Fractionation}

Blood samples were centrifuged at $1000 \times \mathrm{g}$ for $10 \mathrm{~min}$ at $4{ }^{\circ} \mathrm{C}$. Plasma was collected and stored at $-80^{\circ} \mathrm{C}$ until analysis. Erythrocytes were washed 3 times with cold isotonic $0.9 \% \mathrm{NaCl}$ prior to freezing the erythrocyte pellet.

\subsection{Biochemical and Haematological Measurements}

Biochemical measurements in serum were determined using the Horiba ABX Pentra 400 clinical chemistry analyzer with ALT (A11A01627), AST (A11A01629), BUN (A11A01641) and creatinine (A11A01868) kits. Reference intervals were previously calculated using healthy 4-6 month-old Sprague Dawley, Fischer and Wistar rats fed a nutritionally complete rodent chow diet. Haematological parameters were determined using the Beckman Coulter AcT 5 Diff CP haematology analyzer. Plasma Cp activity was measured from its oxidase activity using o-dianisidine dihydrochloride as described [29].

\subsection{Western Blotting}

Erythrocytes were hypotonically lysed by adding 4 volumes of cold $10 \mathrm{mmol} / \mathrm{L}$ Tris $\mathrm{pH} 7.2$ containing a protease inhibitor cocktail (Roche, Laval, Canada) and vortexing. Cellular debris was pelleted by centrifugation $\left(1000 \times \mathrm{g}, 5 \mathrm{~min}, 4^{\circ} \mathrm{C}\right)$ and the supernatant was retained for determination of $\mathrm{Hb}$ concentration using Drabkin's reagent (Sigma, Oakville, Canada) and human haemoglobin as a reference standard (Sigma). Erythrocyte extracts (20 $\mu \mathrm{g} \mathrm{Hb}$ ) were separated over 8-16\% Tris-Glycine gradient gels (Invitrogen, Burlington, Canada) under denaturing and reducing conditions. Gels were simultaneously electroblotted onto a single PVDF Immobilon-P transfer membrane (Millipore, Etobicoke, Canada). The membrane was blocked for $1 \mathrm{~h}$ at room temperature (RT) in TBS-Tween (20 mmol/L Tris, $500 \mathrm{mmol} / \mathrm{L} \mathrm{NaCl,} \mathrm{0.1 \%} \mathrm{Tween} 20$ (v/v), pH 7.5) supplemented with 5\% (wt/v) nonfat dry milk (Bio-Rad, Mississauga, Canada). Membranes were probed with an antibody against CCS (H-7, Santa Cruz Biotechnology, Santa Cruz, CA) at a final concentration of $0.4 \mathrm{mg} / \mathrm{L}$ overnight at $4{ }^{\circ} \mathrm{C}$ in TBS-Tween supplemented with $0.5 \%$ nonfat dry milk. After washing with TBS-Tween, membranes were incubated with an anti-mouse horseradish peroxidise-conjugated secondary antibody (Bio-Rad) at a 1:2500 dilution in TBS-Tween supplemented with $0.5 \%$ nonfat dry milk for $2 \mathrm{~h}$ at RT. 
Antibody-bound proteins were detected by enhanced chemiluminescence using SuperSignal ${ }^{\circ}$ West Dura Extended Duration Substrate (Thermo Scientific, Rockford, IL). Membranes were stripped with stripping buffer (62.5 mmol/L Tris-HCl pH 6.8, 2\% SDS (wt/v), $100 \mathrm{mmol} / \mathrm{L}$ 2-mercaptoethanol) for $30 \mathrm{~min}$ at $55{ }^{\circ} \mathrm{C}$ and re-probed with an antibody against glyceraldehyde-3-phosphate dehydrogenase (GAPDH) (MCA-1D4, Encor Biotech, Alachua, FL) at a 1:1000 dilution. Images were captured with a Chemi Genius² Bio Imaging System (PerkinElmer, Woodbridge, Canada) and the intensities of the bands were quantified using Scion Image software (Scion Corporation, Frederick, MD).

\subsection{Cu Determination in Tissues}

$\mathrm{Cu}$ content in liver and kidney was determined by flame AAS after ashing the tissues as described [30]. $\mathrm{Cu}$ concentrations were presented per gram of dry tissue weight. Plasma $\mathrm{Cu}$ concentration was measured using a SIMAA 6000 graphite furnace AAS with Zeeman background correction (PerkinElmer Cetus Instruments, Shelton, CT). Plasma was diluted 1/20 in demineralised water prior to $\mathrm{Cu}$ determination. $\mathrm{Cu}$ concentrations in tissues and plasma were determined from a standard curve prepared using an NIST-certified reference standard.

\subsection{Statistical Analyses}

Data were analysed by one-way ANOVA and differences between means were determined by Tukey's honestly significant difference (HSD) test or Unequal N HSD test. Data were reported as means \pm SEM. Statistical significance was set at $\mathrm{P}<0.05$. Data were analysed using Statistica 8 software (StatSoft, Tulsa, OK).

\section{Conclusions}

This work is the first demonstration that CCS protein is down-regulated in response to Cu overload in animals. Since erythrocyte CCS content can be measured in a small blood sample, it is appealing as a potential biomarker for assessing $\mathrm{Cu}$ excess. Further research should examine CCS expression in erythrocytes of humans with $\mathrm{Cu}$ overload. Erythrocyte CCS content may prove useful as a biomarker for assessing $\mathrm{Cu}$ overload and as a diagnostic test for disorders of $\mathrm{Cu}$ overload such as Wilson's disease.

\section{Acknowledgements}

The authors thank the Animal Resource Division, Health Canada for care of the rats and help with extraction of tissues during necropsy. We are also grateful to Martha Navarro and Rudi Mueller (Health Products and Food Branch, Health Canada) for pathological examination of the rats. This research was funded by the Bureau of Nutritional Sciences, Health Canada. 


\section{References and Notes}

1. Linder, M.C.; Hazegh-Azam, M. Copper biochemistry and molecular biology. Am. J. Clin. Nutr. 1996, 63, 797S-811S.

2. Bertinato, J.; L'Abbe, M.R. Maintaining copper homeostasis: Regulation of copper-trafficking proteins in response to copper deficiency or overload. J. Nutr. Biochem. 2004, 15, 316-322.

3. Prohaska, J.R. Role of copper transporters in copper homeostasis. Am. J. Clin. Nutr. 2008, 88, 826S-829S.

4. Field, L.S.; Luk, E.; Culotta, V.C. Copper chaperones: Personal escorts for metal ions. J. Bioenerg. Biomembr. 2002, 34, 373-379.

5. Kaler, S.G. Metabolic and molecular bases of Menkes disease and occipital horn syndrome. Pediatr. Dev. Pathol. 1998, 1, 85-98.

6. Lutsenko, S.; Efremov, R.G.; Tsivkovskii, R.; Walker, J.M. Human copper-transporting ATPase ATP7B (the Wilson's disease protein): Biochemical properties and regulation. J. Bioenerg. Biomembr. 2002, 34, 351-362.

7. Machado, A.A.; Deguti, M.M.; Genschel, J.; Cancado, E.L.; Bochow, B.; Schmidt, H.; Barbosa, E.R. Neurological manifestations and ATP7B mutations in Wilson's disease. Parkinsonism Relat. Disord. 2008, 14, 246-249.

8. Bertinato, J.; Zouzoulas, A. Considerations in the development of biomarkers of copper status. $J$. AOAC Int. 2009, 92, 1541-1550.

9. Pilloni, L.; Lecca, S.; Van Eyken, P.; Flore, C.; Demelia, L.; Pilleri, G.; Nurchi, A.M.; Farci, A.M.; Ambu, R.; Callea, F.; Faa, G. Value of histochemical stains for copper in the diagnosis of Wilson's disease. Histopathology 1998, 33, 28-33.

10. Song, Y.M.; Chen, M.D. A single determination of liver copper concentration may misdiagnose Wilson's disease. Clin. Biochem. 2000, 33, 589-590.

11. Faa, G.; Nurchi, V.; Demelia, L.; Ambu, R.; Parodo, G.; Congiu, T.; Sciot, R.; van Eyken, P.; Silvagni, R.; Crisponi, G. Uneven hepatic copper distribution in Wilson's disease. J. Hepatol. 1995, 22, 303-308.

12. Brewer, G.J.; Hill, G.; Prasad, A.; Dick, R. The treatment of Wilson's disease with zinc. IV. Efficacy monitoring using urine and plasma copper. Proc. Soc. Exp. Biol. Med. 1987, 184, 446-455.

13. Ince, A.T.; Kayadibi, H.; Soylu, A.; Ovunc, O.; Gultepe, M.; Toros, A.B.; Yasar, B.; Kendir, T.; Abut, E. Serum copper, ceruloplasmin and 24-h urine copper evaluations in celiac patients. Dig. Dis. Sci. 2008, 53, 1564-1572.

14. McMillin, G.A.; Travis, J.J.; Hunt, J.W. Direct measurement of free copper in serum or plasma ultrafiltrate. Am. J. Clin. Pathol. 2009, 131, 160-165.

15. Culotta, V.C.; Klomp, L.W.; Strain, J.; Casareno, R.L.; Krems, B.; Gitlin, J.D. The copper chaperone for superoxide dismutase. J. Biol. Chem. 1997, 272, 23469-23472.

16. Bertinato, J.; Iskandar, M.; L'Abbe, M.R. Copper deficiency induces the upregulation of the copper chaperone for $\mathrm{Cu} / \mathrm{Zn}$ superoxide dismutase in weanling male rats. J. Nutr. 2003, 133, 28-31.

17. West, E.C.; Prohaska, J.R. Cu,Zn-superoxide dismutase is lower and copper chaperone CCS is higher in erythrocytes of copper-deficient rats and mice. Exp. Biol. Med. (Maywood) 2004, 229, 
756-764.

18. Prohaska, J.R.; Broderius, M.; Brokate, B. Metallochaperone for $\mathrm{Cu}, \mathrm{Zn}$-superoxide dismutase (CCS) protein but not mRNA is higher in organs from copper-deficient mice and rats. Arch. Biochem. Biophys. 2003, 417, 227-234.

19. Hepburn, J.J.; Arthington, J.D.; Hansen, S.L.; Spears, J.W.; Knutson, M.D. Technical note: Copper chaperone for copper, zinc superoxide dismutase: A potential biomarker for copper status in cattle. J. Anim. Sci. 2009, 87, 4161-4166.

20. Bertinato, J.; L'Abbe, M.R. Copper modulates the degradation of copper chaperone for $\mathrm{Cu}, \mathrm{Zn}$ superoxide dismutase by the $26 \mathrm{~S}$ proteosome. J. Biol. Chem. 2003, 278, 35071-35078.

21. Caruano-Yzermans, A.L.; Bartnikas, T.B.; Gitlin, J.D. Mechanisms of the copper-dependent turnover of the copper chaperone for superoxide dismutase. J. Biol. Chem. 2006, 281, 13581-13587.

22. Iskandar, M.; Swist, E.; Trick, K.D.; Wang, B.; L'Abbe, M.R.; Bertinato, J. Copper chaperone for $\mathrm{Cu} / \mathrm{Zn}$ superoxide dismutase is a sensitive biomarker of mild copper deficiency induced by moderately high intakes of zinc. Nutr. J. 2005, 4, 35.

23. Suazo, M.; Olivares, F.; Mendez, M.A.; Pulgar, R.; Prohaska, J.R.; Arredondo, M.; Pizarro, F.; Olivares, M.; Araya, M.; Gonzalez, M. CCS and SOD1 mRNA are reduced after copper supplementation in peripheral mononuclear cells of individuals with high serum ceruloplasmin concentration. J. Nutr. Biochem. 2008, 19, 269-274.

24. Fuentealba, I.; Haywood, S. Cellular mechanisms of toxicity and tolerance in the copper-loaded rat. I. Ultrastructural changes in the liver. Liver 1988, 8, 372-380.

25. Bremner, I.; Mehra, R.K.; Morrison, J.N.; Wood, A.M. Effects of dietary copper supplementation of rats on the occurrence of metallothionein-I in liver and its secretion into blood, bile and urine. Biochem. J. 1986, 235, 735-739.

26. Aburto, E.M.; Cribb, A.; Fuentealba, I.C.; Ikede, B.O.; Kibenge, F.S.; Markham, F. The failure of selenium supplementation to prevent copper-induced liver damage in Fischer 344 rats. Can. J. Vet. Res. 2001, 65, 104-110.

27. Haywood, S.; Loughran, M. Copper toxicosis and tolerance in the rat. II. Tolerance--a liver protective adaptation. Liver 1985, 5, 267-275.

28. Steindl, P.; Ferenci, P.; Dienes, H.P.; Grimm, G.; Pabinger, I.; Madl, C.; Maier-Dobersberger, T.; Herneth, A.; Dragosics, B.; Meryn, S.; Knoflach, P.; Granditsch, G.; Gangl, A. Wilson's disease in patients presenting with liver disease: A diagnostic challenge. Gastroenterology 1997, 113, 212-218.

29. Schosinsky, K.H.; Lehmann, H.P.; Beeler, M.F. Measurement of ceruloplasmin from its oxidase activity in serum by use of o-dianisidine dihydrochloride. Clin. Chem. 1974, 20, 1556-1563.

30. Cockell, K.A.; Fischer, P.W.; Belonje, B. Elemental composition of anatomically distinct regions of rat liver. Biol. Trace Elem. Res. 1999, 70, 251-263.

(C) 2010 by the authors; licensee MDPI, Basel, Switzerland. This article is an Open Access article distributed under the terms and conditions of the Creative Commons Attribution license (http://creativecommons.org/licenses/by/3.0/). 